\title{
Gorbachev encourages change in science as elsewhere
}

\section{London}

THE Soviet Union "must create a qualitatively new Soviet scientific potential", $\mathrm{Mr}$ Mikhail Gorbachev told the nineteenth conference of the Communist Party of the Soviet Union last week. Perestroika in science, he said, is not merely a matter of putting right the mistakes and omissions of the Brezhnev era, the "years of stagnation", when Soviet science fell behind in a number of leading fields, and the social status of science and the prestige of scientific work declined rapidly. Without radical changes in the whole approach to science, he said, it will be impossible to achieve a breakthrough in basic research.

Part of the problem, he acknowledged, is economic. "It is abnormal", he said, that only 6.5 per cent of all the funds allocated for scientific research go to the academic sector of science which carries out the bulk of research". But the problem is not only the amount of money but also how it is allocated. He once again stressed the need to set up "scientific and technical complexes" that would override interdepartmental barriers, the development of financial autonomy for research institutions and the encouragement of contract research. Some scientists, he noted with apparent approval, have been discussing the possibility of "cooperative forms" of organizing science, operating in "a sensible combination" with the state sector.

Another problem is what Gorbachev called the "impeding factors" inherited from the past. Centralized "command methods of management" had frequently meant that priorities had been imposed on scientific research "which did not stem from the logic of its own development", while other new and promising areas either received inadequate support or were forbidden altogether. There must be radical changes in the approach of society to science, he said. "When we make requests of scientists, we must show greater trust and create all the necessary conditions for creativity and their search for what is new." In particular, special attention must be paid to research at the interface of different scientific disciplines, as it is in these areas that "revolutionary break-throughs" are being achieved in all branches of science and technology.

Gorbachev`s 2,000-strong audience of delegates contained 175 scientists and university teachers and 41 medical personnel, of whom 112 were members or corresponding members of the Academy of Sciences of the USSR, the academies of the union republics or the specialized academies. Many scientists, however, had made known their views and needs well before the conference. Scientists from the
Leningrad institutes of the Academy of Sciences of the USSR which, some time back, combined their resources to form the kind of research centre advocated by Gorbachev accused the presidium of the academy of impeding their work by unnecessary bureaucratic restrictions, in particular by forbidding the Leningrad researchers to earn foreign currency and spend it on improving their own facilities. The president of the academy, Dr Gurii Marchuk, himself a delegate to the conference, told the academy presidium that he advocated limiting the tenure of posts in the academy to two successive five-year terms of office. (Gorbachev had originally proposed such a time limit on state and party officials but the proposal was dropped.)

There were also a number of preconference complaints about how delegates were elected - or not elected. Moscow University, in particular, was especially angry when its favoured candi-

date, Professor Popov, described by Moscow radio as "a man well known for his innovative views on perestroika" was rejected by the party committee of Moscow's Lenin Hills District in favour of the university's rector and party secretary.

For other scientists, complaints about professional problems were only part of wider issues. In a pre-conference public meeting in Vilnius, the president of the Lithuanian Academy of Sciences, Dr Juras Pozela, stressed that not only was the financing of science in the Lithuanian SSR poor, it was also "unacceptable in principle", as the Lithuanian government was not free to decide how to allot the available funds.

From this he went on to the general question of Moscow's control over the union republics which, he said, he was prepared to raise at the conference. Why, he asked, do the party second secretaries of these republics have to be nominees of the all-union central committee. Lithuania, he said, echoing the growth of national sentiment in the (formerly independent) Baltic republics, is sufficiently mature to manage without such patronage.

Vera Rich

\section{US space sciences look to the future}

\section{Washington}

STRIKING an upbeat tone, the long-awaited report from the National Research Council's (NRC) space science board on space science in the next century* declares at the outset that the past 25 years have been extraordinarily productive for space science. But the successes have been accomplished in spite of the traditional emphasis at the National Aeronautics and Space Administration (NASA) on putting man into space and accomplishing "large engineering projects for their own sake". The board concludes the time has come to make science and its application to human welfare a central theme of the US programme, alongside manned spaceflight.

The NRC report has had a long gestation. In early 1984, NASA requested a study of the primary scientific issues it would face between 1995 and 2015. The study was essentially complete in late 1986 , but the NRC internal review process took more than a year, and it was only in February this year that the board was able to choose a release date. In the end, the board picked 28 June to coincide with its own thirtieth anniversary.

The report consists of seven volumes: an overview plus six volumes on separate scientific topics - astronomy and astrophysics, life sciences, mission to planet Earth, fundamental physics and chemistry, solar and space physics, and planetary and lunar exploration.

Thomas Donahue, chairman of the National Academy of Sciences space science board for the past six years, says that he hopes the report will be useful as a new White House administration puts together its agenda for space. Donahue is particularly enthusiastic about work done by the task group on fundamental physics and chemistry. Microgravity studies such as the lambda point experiment which measures the heat capacity of liquid helium through its transition from superfluid phase, or potential studies of 'fractal aggregates' - a tenuous form of a space-filling solid - may make possible a new understanding of basic physical science.

But the chief problem facing space science is its constant need to compete with the more resource-hungry manned space programme within NASA. Donahue feels that an independent space science institute, possibly structured along the lines of the National Center for Atmospheric Research in Boulder, Colorado, is an idea worth investigating. $\mathrm{He}$ also argues that space science should be budgeted at its full cost so it is not beholden to the space shuttle for access to space.

But Lennard Fisk, associate administrator of NASA and head of the office of space science and applications, does not feel that splitting space science off from NASA would be a good thing. Fisk says it would be too hard to determine precisely where operational programmes end and space science begins to make a separate institute a viable entity. Joseph Palca * Space science in the twenty-first century: imperatives for the decades 1995-2015. National Academy Press, Washington. DC. 1988. 